Eva Kellner has a PhD in plant physiology and is university lecturer in biology at the University of Gävle. She has long experience in teaching biology in teacher education and her research focus is teacher professional development and pupil learning in biology.

liris Attorps is university lecturer and associate professor in mathematics education at the University of Gävle. She has long experience in teaching of mathematics for prospective teachers and engineers. Her research interest is teaching and learning of mathematics in compulsory school as well as on university level.

\title{
EVA KELLNER
}

Faculty of Engineering and Sustainable Development, University of Gävle, Sweden

ekr@hig.se

\section{IIRIS ATTORPS}

Faculty of Engineering and Sustainable Development, University of Gävle, Sweden ias@hig.se

\section{Primary school teachers' concerns and needs in biology and mathematics teaching}

\begin{abstract}
The aim of this paper is to provide insights into nine primary school teachers' concerns and instructional needs in biology and mathematics, grades 1 to 6. By using Content Representation, combined with Learning Study in an action research project, teachers were encouraged to reflect on their conceptions, processes of instructing and pupil learning. From concerns articulated by teachers three instructional needs emerged: (i) to make subject progression, especially in biology, and pupil learning more visible, (ii) to develop mathematics teaching in order to change pupils' views of the subject, and (iii) to develop teachers' subject matter knowledge and teaching in an ongoing collaborative process. The paper argues that in order to stimulate teacher professional development it is important to make teacher concerns and thereby needs explicit. They help teachers to identify and reflect on relations between teacher subject matter knowledge, pedagogical content knowledge and pupil learning.
\end{abstract}

\section{INTRODUCTION}

It is shown that identifying teaching concerns and needs help student teachers to gain new insights into their teaching and by this into their own learning (Nilsson, 2009). Also among experienced teachers there is a continuous need to develop the professional knowledge. Teacher professional development is a complex process that includes the cognitive and emotional involvement of teachers, both individually and collaboratively (Avalos, 2011). Teachers typically have limited opportunities to collaborate with others who can offer them support in their instructional practices. They experience a need for change, but they often seek out opportunities for development on their own. It seems to be a consensus in the literature that active and collaborative participation in professional learning communities (PLCs), which involve teachers meeting on a regular basis for the purpose of joint learning 
and lesson planning, is a crucial factor in high-quality professional development (Borko, Jacobs, \& Koellner, 2010). Teachers in such communities seek continuous improvement in their daily practices. Studies indicate that a well-functioning PLC can have a positive impact on teaching practice and pupil achievement (Vescio, Ross, \& Adams, 2008).

In this action research study we applied two methodological tools; Learning Study (LS) (Pang, 2006; Pang \& Ling, 2012) combined with Content Representation (CoRe) (Loughran, Mulhall, \& Berry, 2004), in order to encourage teachers to reflect on aspects of teacher knowledge in their instructional practices and thereby provide insights into their concerns and needs. The study was guided by the following two research questions:

1. What concerns are expressed by teachers when reflecting on aspects of teacher knowledge in their professional practices in biology and mathematics, grades 1 to 6 ?

2. What needs are emerging when teachers collaboratively discuss teacher knowledge and concerns?

\section{CONCEPTUAL FRAMEWORK}

\section{Insights into teacher knowledge and professional development}

Action research is one way to gain insight into the practices of teachers, their knowledge of those practices, and their professional development. It also gives possibilities for teachers to collaboratively participate in professional learning communities (PLCs). Action research commonly focuses on problematic areas and concerns identified by participants themselves. An active participation is a prerequisite if a change in their practice is to occur. In action research participants are viewed as involved subjects, and not merely as study objects. They must reflect on their situation and then function as active partners in the research (Kemmis, 2009; McNiff, 2002; Patton, 2002; Zeichner \& Noffke, 2001). Teachers must also consider various aspects of teacher knowledge in their professional development. The model of teacher knowledge by Grossman (1990) has grown out of Shulman's framework $(1986,1987)$. It consists of four parts: subject matter knowledge (SMK), general pedagogical knowledge, knowledge of context, and pedagogical content knowledge (PCK). The last named, PCK, can be defined as the special knowledge used by the teacher to transform his/her SMK to benefit students (Grossman, 1990; Magnusson, Krajcik, \& Borko, 1999). There is no universally accepted conceptualization of PCK, but it has been found to be a useful tool for understanding the professional practices of teachers (Kind, 2009).

According to Kind (2009) applying CoRe as a methodological tool offers a unique insight into teacher knowledge and practices relating to specific topics. The CoRe document provides an overview of teaching approaches and elicits reasons for teaching decisions. It addresses different issues of PCK, in conjunction with the content (ideas) to be taught in the classroom. Examples of the issues in CoRe are; What do you intend that students should learn about this idea?, Why is it important for students to know this?, Specific ways of ascertaining students' understanding or confusions around these ideas. (see Loughran et al., 2004, p. 376). Teachers can use the CoRe document as a pedagogical as well as collaborative tool when planning lessons. It helps them identify important aspects of the content and clarifies their conceptions and decisions about teaching particular topics. After lessons are taught, teachers' experiences can be documented (either individually or collectively) by means of "Pedagogical and Professional-experience Repertoires" (PaP-eRs), documents that are associated to CoRe (Loughran et al., 2004, p. 376). These documents illuminate the decisions underpinning the teacher's actions and are intended to help the learners better understand the content being taught. CoRe and PaP-eRs have been used, for example, to develop prospective teachers' professional knowledge of teaching (Loughran, Mulhall, \& Berry, 2008; Nilsson \& Loughran, 2012), and primary school teachers' understanding of their professional knowledge and their teaching of science (Bertram \& Loughran, 2012). 
Teachers can also gain insight into their teaching practices and concerns by conducting research 'lesson studies'. These studies originate from Japan and generally involve small groups of teachers from the same grade level, content area, or both. Lesson studies provide a modality for articulating teachers' uncertainties, decision making, and reflective processes (Marble, 2006; Lewis, Perry, \& Murata, 2006). They are a form of participatory teacher research with clear objectives to be achieved and data to be collected for critical analyses in a cyclic process. Lesson studies have encouraged teachers to collaborate on issues they normally confront alone (Puchner \& Taylor, 2006). Although time consuming and impractical to apply in the case of every lesson, Lee (2008) suggests that the impacts of intensive work on a few research lessons can be extensive. Lesson studies enable teachers to take charge of their own professional development by setting their agendas and selecting the objectives for their studies. The critical difference between lesson study and Learning Study (LS) is the presence of a learning theory, termed variation theory (Marton \& Morris, 2001). In this theory a crucial assumption is that variation is a prerequisite for discerning critical aspects of the object of learning. When teachers and researchers explicitly apply this theory in planning, conducting, and revising lessons, those projects are called LS (Marton \& Pang, 2006; Pang \& Ling, 2012). The cyclic process in LS starts with choosing and defining the object of learning in a specific problematic subject area. Previous teaching experiences and research on the topic or concept become the point of departure for designing a pre-test to be used for diagnostic purpose. The results of the pre-test assist the teachers in planning the first lesson. Experiences from the lesson and the results of a post-test are then analyzed. If pupil learning outcomes, with regard to the stated aims, are not satisfactory the lesson is revised. Finally, another teacher implements the new lesson plan in his/her class. This cyclic process continues until the critical factors for pupil learning are discerned.

There is insufficient research into ways of capturing and describing concrete examples of teaching practices related to specific subject areas (Abell, 2008; Bertram \& Loughran, 2012). In order to capture concreate examples of teaching practices we argue that it is important to make teachers' subject specific and instructional concerns and needs explicit. In this action research project, CoRes were combined with LS to create supportive conditions for primary school teachers' collaboration and to provide insight into their needs, based on their experiences and concerns in teaching biology and mathematics.

\section{METHODS}

\section{Research design}

The current study is a part of a four year longitudinal action research project, and it covers the first one and a half year of the project. Our intention in this part of the project was to provide insight into primary school teachers' concerns and instructional needs in biology and mathematics. In our research design we applied Learning Study (LS) (Pang, 2006; Pang \& Ling, 2012) combined with CoRe (Loughran et al., 2004) in order to encourage teachers to reflect on aspects of teacher knowledge in their instructional practices and thereby provide insight into their concerns and needs. These methodological tools have been used to make the unexpressed nature of teacher knowledge explicit (Kind, 2009; Little, 2004). Bertram and Loughran (2012), also point out that CoRe is valuable in the process of teacher professional development.

\section{Participants}

A total of nine primary school teachers and two researchers participated in the study. The teachers all taught mathematics and science at the same school in grade 1 to 6 (7 to 12-year-olds). Each of them had more than five years experience in teaching at elementary school, but most lacked competence in science, i.e. they had not studied required university courses in science. Three of the teachers attended a continuing education course in science and technology at the university. These teachers were interested in starting collaboration between the university and their primary school, and after discussions with their school principal and colleagues the project started. 


\section{Data collection}

The teachers' discussions concerning different aspects of teacher knowledge and their concerns were collected by audio-recordings of group discussions during three follow-up meetings (one in biology, one in mathematics and one in both of the subjects) after conducted lessons.

\section{Research process}

During the first semester three action research meetings took place at which the project design was formulated. The following six sessions extended over two semesters and were about subject matter content, pupil conceptions, lesson planning, implementation, and reflections on the teaching sequences. All meetings were held at the local public school where the study was conducted.

At the initial research meeting the overall aim of the project was discussed as deepening teacher understanding of their practices. Furthermore, the ethical aspects of conducting action research were discussed and agreed upon. Action research requires adherence to a mutually agreed-upon framework governing the collection, use, and publication of data. A dialogue between researchers and teachers is needed to ensure the free flow of information between participants. The teachers can consult the researchers' data and interpretations, and the researchers have access to the teachers' documentations and comments. Participants are also free to withdraw from the project at any time.

Action research usually originates from the problematic areas expressed by teachers themselves. In this study the teachers were asked to discuss and identify the content areas they found the most problematic in teaching biology and mathematics. They cited the complex relationships and concepts surrounding ecosystems and the transition from arithmetic to algebra, both major topics in the Swedish curriculum.

In order to create a link between theory and practice the researchers, at the beginning of the second semester, introduced LS, and CoRes in the teacher team. The project team discussed and decided to combine these tools in the project for the grades 1 to 6 . Permissions were obtained from guardians to document classes by photos, and by collecting data from tests and teaching materials. The problematic areas in biology and mathematics were also discussed, keeping the intentions of the syllabuses in mind. The teachers used CoRes and pre- and post-tests within LS, when planning, conducting and revising their lessons.

During the last semester there were three follow-up meetings concerning the conducted lessons in biology and mathematics. In preparation for the first two meetings, the teachers were asked to bring their CoRes and documentations from lessons and tests in biology and mathematics. During the sessions the teachers presented the activities they had done with each grade. They highlighted and reflected on different aspects of teacher knowledge based on their experiences. The discussions were recorded and documented by the researchers. At the last meeting the teachers were asked to further reflect on and discuss the aspects of teacher knowledge highlighted during the first two meetings.

\section{Data analysis}

The teachers' discussions during the two first follow-up meetings were analyzed with focus on aspects of teacher knowledge. We applied the models of teacher knowledge by Grossman (1990) and PCK by Magnusson et al., (1999) as a theoretical framework for analyzing our data. These models were chosen since they include curricular knowledge and assessment, both central elements in this project.

The analysis of the transcribed discussions was done by pattern coding (Miles \& Huberman, 1994). In the first-level coding data coincided with three out of four main components of Grossman's teacher knowledge; PCK, SMK, and Knowledge of Context. By using pattern coding, similar segments of data concerning the three main aspects of teacher knowledge were then grouped into qualitatively dif- 
ferent sub-aspects as shown in Table 1. It illustrates which main aspects and sub-aspects of teacher knowledge that were highlighted during the first two follow-up meetings and then further discussed by teachers during the third meeting.

Table 1. Main aspects and sub-aspects of teacher knowledge highlighted by teachers.

\begin{tabular}{|c|c|c|c|c|}
\hline Main aspects & Sub-aspects & & & \\
\hline $\begin{array}{l}\text { Pedagogical Content } \\
\text { Knowledge (PCK) }\end{array}$ & $\begin{array}{l}\text { Assessment } \\
\text { (pre- and post- } \\
\text { tests) }\end{array}$ & $\begin{array}{l}\text { Pupils' } \\
\text { pre-knowledge }\end{array}$ & $\begin{array}{l}\text { Instructional } \\
\text { strategies }\end{array}$ & $\begin{array}{l}\text { Knowledge of } \\
\text { curriculum }\end{array}$ \\
\hline $\begin{array}{l}\text { Subject Matter } \\
\text { Knowledge (SMK) }\end{array}$ & \multicolumn{4}{|c|}{ The importance of teachers' subject knowledge } \\
\hline Knowledge of Context & \multicolumn{4}{|c|}{ Access to educational materials } \\
\hline
\end{tabular}

In the next step of analysis the transcribed discussions from all three meetings were correlated to teacher concerns. Teacher concerns are defined as issues that teachers felt anxious or worried about (e.g., unsufficient subject knowledge or lack of clear subject progression). By pattern coding, the summarized segments of data concerning teacher concerns were divided into qualitatively different themes. From these themes instructional needs were emerged. Instructional needs are defined as things to be done that might improve teaching practice and pupil learning.

In order to establish the reliability of data analysis, the transcriptions were coded by the researchers independently. They then compared and discussed the coding with respect to the different themes until consensus was reached. Furthermore, the concerns and the needs emerging from the data were presented to the teachers, discussed and justified by the team, in order to establish the validity of the data (McNiff, 2002).

\section{RESULTS}

\section{Primary school teachers' concerns and instructional needs}

When analyzing the teachers' concerns they were grouped into three different themes; Lack of transparency and focus, Static view of mathematics, and Collaborative development (Table 2). From these themes of concerns three instructional needs emerged; To make subject progression and pupil learning more visible, To develop mathematics teaching in order to change pupils' views of the subject, and To develop teacher subject matter knowledge and teaching in an ongoing collaborative process (Table 2).

\section{To make subject progression and pupil learning more visible}

The primary school teachers concluded that knowing how to interpret and implement the intention of the biology syllabus is essential for improving the quality of teaching and learning. They found it problematic that the progression of topics in biology is not as clear as it is in mathematics. They stated also that compared with mathematics there were few biology textbooks available at the school, helping them to make subject progression clearer.

It has been a tradition in mathematics for many years that this topic will be taught in the first grade, the second grade, etc. The progression is clear. We are not given the progression in biology in the same way. This makes a big difference, and it makes it more difficult to assess what a class already knows in biology. (Elisabeth)

In biology, it is not obvious what the core content is and what to build on ... It is not clear where to start. I think you might miss certain things if it is not clear. Also, it might be easier for a 
teacher to plan when we know how concepts are connected. You need a base to build up pupils' knowledge ... in order to be able to discuss subject aspects at a higher level ... In biology we do not have textbooks available, but in mathematics we do. (Christine)

The teachers stated that to help pupils develop their understanding, it is important to focus on the most important concepts over and over. Therefore, the most essential aspects of the subject must first be identified.

When you are teaching you have to reflect on what is critical in math, what you have to repeat. Similarly, what is fundamental in biology, what recurs, what is the basis for everything? (Elisabeth)

Although the progression is more obvious in mathematics, teachers found that they must reflect upon the major ideas in order to help pupils improve their comprehension. They realized how easy it is to simply provide the correct answers in mathematics without being concerned to develop pupil understanding.

Unless you consider what is essential in a subject, your teaching will not go beyond what is contained in the textbook or in the assignments you give. (Eveline)

We can usually give the answers to mathematics problems, although we may not always make the effort to elaborate the reasoning behind them. (Christine)

They also found pre- and post-tests as a useful tool visualizing pupils' learning in biology, helping them to discover what they already knew, and confirming what they had recently learned.

Pupils find it enjoyable when they have learned something. They can see on paper how little they knew at the beginning. Then you work with them and give them the same test again, and suddenly they say: This is easy now! I've learned a lot! (Elisabeth)

Table 2. Instructional needs emerging from teachers' concerns.

\begin{tabular}{|c|c|}
\hline Themes of concerns & Instructional needs \\
\hline $\begin{array}{l}\text { Lack of transparency and focus } \\
\text { - Unclear progression in biology teaching } \\
\text { - Lack of biology textbooks } \\
\text { - Unsufficient focus on important concepts } \\
\text { - Difficulties to visualize and evaluate pupil learning }\end{array}$ & $\begin{array}{l}\text { To make subject progression } \\
\text { and pupil learning more visible }\end{array}$ \\
\hline $\begin{array}{l}\text { Static view of mathematics } \\
\text { - Mathematic only a school subject } \\
\text { - Traditionally considered difficult } \\
\text { - Competitive subject with high status } \\
\text { - Mathematics only calculation }\end{array}$ & $\begin{array}{l}\text { To develop mathematics teach- } \\
\text { ing in order to change pupils' } \\
\text { views of the subject }\end{array}$ \\
\hline $\begin{array}{l}\text { Collaborative development } \\
\text { - Insufficient subject matter knowledge } \\
\text { - Relevant tests } \\
\text { - Unstructured lesson planning time } \\
\text { - Time for collaborative work }\end{array}$ & $\begin{array}{l}\text { To develop teacher subject } \\
\text { matter knowledge and teach- } \\
\text { ing in an ongoing collaborative } \\
\text { process }\end{array}$ \\
\hline
\end{tabular}




\section{To develop mathematics teaching in order to change pupils' views of the subject}

The teachers found it essential to consider pupils' traditional views of mathematics. One of the deeply-rooted perceptions of pupils is that mathematics is unrelated to the real world.

Many pupils believe that math is only a school subject; you do it at school, but you do not need it at home. But biology is your whole world, at home and everywhere. I think that is the difference. (Christine)

If you ask where you can use math, the children respond, "In school!" (Elisabeth)

They spoke of the complexity of both mathematics and science, and reported that although pupils find mathematics hard, they do not complain that biology is difficult. Biology is not traditionally seen as complex, probably due to its visible connection to everyday life.

Elisabeth: Science is difficult, although there are not many pupils who say so.

Christine: There is a thirst for knowledge in science.

Elisabeth: Some concepts are undoubtedly difficult. For example, it is really hard to understand fertilization in plants. Certainly it is difficult, but pupils do not talk about it the way they do about mathematics. It is a tradition.

Elisabeth: One pupil said to me during lunch, "I've been thinking about something: how can there be oxygen in the winter, there is no photosynthesis then?" I answered that there is oxygen in the atmosphere, which is very large ... Pupils watch nature programs on TV and they really enjoy them. How many pupils have seen math programs?! They are very few. There are many things in everyday life you are exposed to that have to do with biology.

When pupils are asked to discuss everyday problems in mathematics, they prefer to work on exercises in their books instead. They do not grasp the fact that problem solving is real mathematics. Pupils perceive mathematics as a prestigious subject and feel they are competing with their classmates when working on math exercises.

Eveline: Mathematics has a high status and pupils think one needs to be smart to succeed at it. If you are good in math, they think, then you will do well in life.

Sofie: When we have discussions in math classes pupils often say, "Shouldn't we be doing mathematics instead?" If you talk with pupils about mathematics problems and ask them if they consider it mathematics, their answer is "No".

Elisabeth: That is not the case in biology.

Christine: If we ask pupils what mathematics is, they answer that "it is to sit down and do exercises in the textbook".

Eveline: It is a bit like a race. Pupils want to finish their math exercises quickly, although we try to explain that the most important thing is not to do all the exercises but to understand what you are doing.

Elisabeth: Competition like this does not exist in science.

Christine: Pupils do not know what the next step is [in biology]; they really have no idea. But in math they know that this is where you are in the book and this is where I am. I have done the most exercises in the book, so that makes me first!

Most activities in biology are carried out in groups and include discussions about the assignment. Teachers agreed that discussions increase pupil understanding in both biology and mathematics. Teaching mathematics, in a way similar to biology, seems to be problematic, due to the negative views pupils have on group activities in mathematics. 
Elisabeth: There is more individual work in math than in the sciences, where there is hardly any individual work. We nearly always sit together in groups and discuss things [in science classes]. Maybe that is way pupils think biology is fun.

Agnes: When you do laboratory work in biology or in other sciences it is really fun. That is what pupils say ... But practical activities in math are not as much fun, although pupils may learn as much as in biology ... Older pupils find it embarrassing to use manipulatives, like money in mathematics.

Christine: I think it is a matter of prestige. If you need to use manipulatives, you must not be smart. You should be doing mental calculations instead. You ought to be able to solve math problems by yourself.

The teachers shared their experiences in trying to prevent competition in mathematics classrooms. One teacher did not allow pupils who had done their exercises in the chapter to proceed to the next one. Instead, they were encouraged to deepen their knowledge by doing additional more challenging exercises. In summary, in order to change pupils' views in mathematics, teachers suggested that teaching should be organized avoiding competition. They believed that less competition in the classroom would make it easier to include more everyday life problems. This would increase collaborative activities and engagement in the subject.

\section{To develop teacher subject matter knowledge and teaching in an ongoing collaborative process}

It was stressed that in order to visualize subject progression and develop understanding of core content, teachers need time for collaborative lesson preparation and reflection. Moreover, if they are to maintain and increase their subject knowledge, teachers need continuing education programs and ongoing conscious discussions about teaching. The teachers valued collaborative work, but such work must be organized and structured, and for this purpose a subject coordinator is desirable.

Elisabeth: One always needs more subject matter knowledge. Updating is always helpful. Research will keep a subject up to date ... There should be someone who is a subject coordinator in charge of leading the collaborative work... It was sometimes too much idle talk in our meetings. Ifeel we need to be more structured.

One example of collaboration is when teachers work together to prepare pre- and post-tests for eliciting pupils' prior knowledge and measuring their subsequent learning. Such tests must be carefully planned and then revised as needed.

Sofie: If we together construct a test it must be adequate for assessing what we want it to measure, and this is time consuming.

Christine: After you have given your class a test, it may occur to you that another aspect should also have been included in the test. It was not obvious when the test was constructed and therefore you [the group] have to revise it.

The teachers were assigned a common lesson planning time every second week. They argued that this time for collaboration is necessary, but it must be well organized in order to stimulate their professional development.

\section{DISCUSSION}

The aim of this study was to make explicit teachers' subject specific instructional concerns and needs. Two of the instructional needs ("to make subject progression and pupil learning visible" and "to develop teacher subject matter knowledge and teaching in an ongoing collaborative process"), highlighted the relation between SMK, PCK and pupil learning. The teachers pointed out the importance 
to develop their SMK in order to make the intention of the syllabuses as well as subject progression clearer, and thereby increase their possibility to improve teaching and pupil learning. This affirms that SMK plays a central role in teacher professional development (Bausmith \& Barry, 2011) and that it has a strong connection to development of PCK and pupil learning. The results in our study also confirm earlier research findings that elementary school teachers often have limited SMK in science (Appleton, 2008; Smith \& Neale, 1989) and that they tend to lack confidence in their adequacy as teachers (Appleton, 2006; Fleer, 2009).

The teachers' experiences of the use of pre- and post-tests also illustrate a relation between their PCK and pupil learning. Their conscious reflections and use of the tests helped them to assess pupil preknowledge and their subsequent learning and thereby to develop their teaching. Moreover, using the tests as pedagogical tools gave pupils insight into their own learning process.

Our results also reveal a need "to develop teaching in an ongoing collaborative process". The teachers stressed the importance of a collaborative way of working in order to stimulate their professional development and thereby teaching. In line with our results, earlier research has shown that opportunities for teachers to work collaboratively on student learning also result in better instruction (Saunders, Goldenberg, \& Gallimore, 2009). Research by Lewis (2005) points out that the collaborative way of working, applied in lesson studies (LS in our study), improves teacher thinking and practice. It develops SMK, increases the ability to observe students, and it results in stronger collaborative networks. This agrees with research (Avalos, 2011; Vescio et al., 2008) that underlines the importance of teacher co-learning as a powerful factor in changing teaching practice. In accordance with the teachers' experiences in this study, Avalos (2011) states that it is necessary to move from ineffective co-learning through casual talk to more organized and effective PLCs that include observations, reflections, and feedback. Research on teacher professional development and PLC also emphasizes the need for teachers to master the content they teach and to understand how students learn that content (Bausmith \& Barry, 2011). However, SMK and the way students learn are not often addressed in the PLC literature (Bausmith \& Barry, 2011). Meanwhile, increasing evidence shows that focusing on subject matter content and how students learn that content can improve their achievement (Dopplet, Schunn, Silk, Mehalik, Reynolds, \& Ward, 2009). Similarly, the teachers in our study pointed out the importance of SMK in order to develop teaching and pupil learning.

In this project the teachers taught biology as well as mathematics and the design of the project created conditions for them to make visible differences between teaching these two subjects. They stated that most activities in biology are carried out in groups and include discussions about the assignments, which are often related to everyday life. This is usually not the case in mathematics teaching. The Swedish syllabus in mathematics states that pupils should be given opportunities to reflect on the use and limitations of mathematics in daily life, and as a result be able to see the context and relevance of mathematics (The Swedish National Agency for Education, 2011). The teachers expressed that, in order to implement the intention of the syllabus, teaching of mathematics should be organized to change pupil traditional static view of the subject, by avoiding competition in the classroom. Knowledge requirements for science and mathematics are defined for grade 3 , and for the science subjects and mathematics for grades 6, and 9, including target grade levels for the individual science subjects or in science and in mathematics. Teachers themselves decide when and how the core concepts are to be implemented for each grade. In this project the teachers perceived the progression of teaching, the hierarchical sequence of key concepts and instruction, as unclear especially with regard to biology. The teachers stated that they are not sufficiently supported by the syllabus.

According to Abell (2008) most research in teacher knowledge in science education is based on studies that are descriptive in nature. We do not know enough about the transformation of subject matter knowledge in practice (Abell, 2008; Bausmith \& Barry, 2011). Abell points out that the shift from description to explanation requires new research designs, including the use of mixed methods in lon- 
gitudinal time frames. In this paper we have presented the first one and a half year of a four year longitudinal action research project. Our research design combined LS with CoRe in order to encourage teachers to reflect on aspects of teacher knowledge in their instructional practices. The design presupposed and stimulated the teachers to collaborate and enabled a conscious discussion of a broad range of teaching aspects in biology and mathematics. It provided insight into their concerns and needs and stimulated professional development. The results indicate that the development of SMK and teaching in an ongoing collaborative process is crucial for professional development. Furthermore, the results show that making teachers' concerns and needs explicit help them to identify and discuss relations between important aspects of teacher SMK, PCK and pupil learning (c.f. Abell, 2008; Bausmith \& Barry, 2011). In this respect, our results contribute to shed light on the questions set by Abell (2008) "What is the relation of PCK to teacher practice?" and "What is the relation of PCK to student learning?"

\section{ACKNOWLEDGMENTS}

The authors wish to thank the University of Gävle, Sweden, and The Swedish International Development Cooperation Agency for their financial support.

\section{REFERENCES}

Abell, S. K. (2008). Twenty Years Later: Does pedagogical content knowledge remain a useful idea? International Journal of Science Education, 30(10), 1405-1416.

Appleton, K. (2006). Science pedagogical content knowledge and elementary school teachers. I K. Appleton (Ed.) Elementary science teacher education. International perspectives on contemporary issues and practice (s. 31-54). Dordrecht, The Netherlands: Springer Academic Press.

Appleton, K. (2008). Developing science pedagogical content knowledge through mentoring elementary teachers. Journal of Science Teacher Education, 19, 523-545.

Avalos, B. (2011). Teacher professional development in Teaching and Teacher Education over ten years. Teaching and Teacher Education, 27(1), 10-20.

Bausmith, J. M., \& Barry, C. (2011). Revisiting professional learning communities to increase college readiness: The importance of pedagogical content knowledge. Educational Researcher, 40(4), $175-178$.

Bertram, A., \& Loughran, J. (2012). Science teachers' views on CoRes and Pap-eRs as a framework for articulating and developing pedagogical content knowledge. Research in Science Education, 42, 1027-1047. doi: 10.1007/s11165-011-9227-4.

Borko, H., Jacobs, J., \& Koellner, K. (2010). Contemporary approaches to teacher professional development. In P. L. Peterson, E. Baker, \& B. McGaw (Eds.), International encyclopedia of education (3rd ed.), Vol. 7 (pp. 548-556). Amsterdam: Elsevier.

Doppelt, Y., Schunn, C. D., Silk, E. M., Mehalik, M. M., Reynolds, B., \& Ward, E. (2009). Evaluating the impact of a facilitated learning community approach to professional development on teacher practice and student achievement. Research in Science and Technology Education, 27(3), 339-354.

Fleer, M. (2009). Supporting scientific conceptual consciousness or learning in "a roundabout way" in play-based contexts. International Journal of Science Education, 31(8), 1069-1089.

Grossman, P. L. (1990). The making of a teacher: Teacher knowledge and teacher education. New York: Teachers College Press.

Kemmis, S. (2009). Action research as a practice-based practice. Educational Action Research, 17(3), $463-474$.

Kind, V. (2009). Pedagogical content knowledge in science education: Perspectives and potential for progress. Studies in Science Education, 45(2), 169-204.

Lee, J. F. K. (2008). A Hong Kong case of lesson study-Benefits and concerns. Teaching and Teacher Education, 24(5), 1115-1124.

Lewis, C. (2005). How do teachers learn during lesson study? In P. Wang-Iverson, \& M. Yoshida (Eds.), Building our understanding of lesson study (pp. 77-84). Philadelphia: Research for Better Schools, Inc. 
Lewis, C., Perry, R., \& Murata, A. (2006). How should research contribute to instructional improvement? The case of lesson study. Educational Researcher, 35(3), 3-14.

Little, J.W. (2004). "Looking at student work" in the United States: Countervailing impulses in professional development. In C. Day \& J. Sachs (Eds.), International Handbook on the Continuing Professional Development of Teachers (pp. 94-118). Buckingham, UK: Open University.

Loughran, J., Mulhall, P., \& Berry, A. (2004). In search of pedagogical content knowledge in science: Developing ways of articulating and documenting professional practice. Journal of Research in Science Teaching, 41(4), 370-391.

Loughran, J., Mulhall, P., \& Berry, A. (2008). Exploring pedagogical content knowledge in science teacher education. International Journal of Science Education, 30(10), 1301-1320.

Magnusson, S., Krajcik, J., \& Borko, H. (1999). Nature, sources, and development of pedagogical content knowledge for science teaching. In J. Gess-Newsome, \& N. G. Lederman (Eds.), Examining pedagogical content knowledge: The construct and its implications for science education (pp. 95-132). Dordrecht: Kluwer.

Marble, S. T. (2006). Learning to teach through lesson study. Action in Teacher Education, 28(3), 86-96.

Marton, F. \& Morris, P. (Eds.). (2001). What Matters? Discovering critical conditions of classroom learning. Göteborg studies of educational sciences. Göteborg: Acta Universitatis Gothoburgensis.

Marton, F., \& Pang, M. F. (2006). On some necessary conditions of learning. Journal of the Learning Sciences, 15(2), 193-220.

McNiff, J. (2002). Action Research: Principles \& Practice. New York: Routledge/Falmer.

Miles, B., \& Huberman, A. (1994). Qualitative data analysis. 2nd ed. Thousand oaks, CA: Sage.

Nilsson, P. (2009). From lesson plan to new comprehension: exploring student teachers' pedagogical reasoning in learning about teaching. European Journal of Teacher Education, 32(3), 239-258.

Nilsson, P., \& Loughran, J. (2012). Exploring the development of pre-service science elementary teachers' pedagogical content knowledge. Journal of Science Teacher Education, 23(7), 699-721.

Patton, M.Q. (2002). Qualitative Research and Evaluation Methods. Thousand Oaks, CA: Sage Publications.

Pang, M. F. (2006). The use of learning study to enhance teacher professional learning in Hong Kong. Teaching Education, 17(1), 27-42.

Pang, M. F., \& Ling, L. M. (2012). Learning study: Helping teachers to use theory, develop professionally, and produce new knowledge to be shared. Instructional Science, 4O(3), 589-606.

Puchner, L. D., \& Taylor, A. R. (2006). Lesson study, collaboration and teacher efficacy: Stories from two school-based math lesson study groups. Teaching and Teacher Education, 22(7), 922-934.

Saunders, W. M., Goldenberg, C. N., \& Gallimore, R. (2009). Increasing achievement by focusing grade-level teams on improving classroom learning: A prospective, quasi-experimental study of Title I schools. American Educational Research Journal, 46(4), 1006-1033.

Shulman, L. S. (1986). Those who understand: Knowledge growth in teaching. Educational Researcher, 15(2), 4-14.

Shulman, L. S. (1987). Knowledge and teaching: Foundation of the new reform. Harvard Educational Review, 57(1), 1-22.

Smith, D.C. \& Neale, D.C. (1989). The construction of subject matter knowledge in primary science teaching. Teaching and Teacher Education, 5(1), 1-20.

The Swedish National Agency for Education (2011). Curriculum for the compulsory school, preschool class and the recreation centre. http://www.skolverket.se/publikationer?id=2687 (Accessed 2015-01-20).

Vescio, V., Ross, D., \& Adams, A. (2008). A review of research on the impact of professional learning communities on teaching practice and student learning. Teaching and Teacher Education, 24(1), $80-91$.

Zeichner, K. M., \& Noffke, S. E. (2001). Practitioner research. In V. Richardson (Ed.), Handbook of research on teaching (4th ed.), (pp. 298-330). Washington, DC: American Educational Research Association. 